Revista Iberoamericana, Vol. LXVIII, Núm. 198, Enero-Marzo 2002, 137-152

\title{
SARMIENTO: \\ LECTOR DE IMÁGENES, ESCRITOR DE PRODIGIOS
}

POR

Graciela Batticuore

Universidad de Buenos Aires

ESCENAS DE FAMILIA. LA FORMACIÓN DEL LECTOR

Al comienzo de uno de los libros sin duda más leídos del siglo XIX, uno de los autores también más polémicos de la centuria escribe sobre los orígenes de su afición por las letras:

\begin{abstract}
Yo sentí antes de pensar; esa es la suerte común de la humanidad. Lo experimenté más que ningún otro. Ignoro lo que hice hasta los cinco o seis años. No sé cómo aprendí a leer; sólo me acuerdo de mis primeras lecturas y de su efecto sobre mí. Ese es el tiempo del que data sin interrupción la conciencia de mí mismo. Mi madre había dejado algunas novelas que mi padre y yo leíamos después de cenar. Por el momento sólo se trataba de ejercitarme en la lectura con libros divertidos; pero pronto nuestro interés fue tan vivo que leíamos aquéllos libros, uno a uno sin interrupción y pasábamos las noches en aquella ocupación. No podíamos dejarlos hasta terminar. Algunas veces mi padre, oyendo por la mañana a las golondrinas, decía avergonzado: "Vamos a acostarnos; yo soy más niño que tú”. (Rousseau 5)
\end{abstract}

Inscripto en las primeras páginas de las Confesiones de Juan Jacobo Rousseau publicadas en 1781 y 1788-, este pasaje exalta la pasión lectora del autor como una marca de origen. La escritura de este recuerdo intenta capturar de entrada a los lectores de la obra: la casa natal, los libros de la niñez, también las golondrinas que asaltan la mañana de una noche poblada de libros impregnan de poesía el comienzo de las Confesiones, procurando explicar así la historia de un “corazón sensible”, el de Rousseau. La historia de ese corazón apasionado y polémico tendría su origen, según el propio dueño, en las lecturas tempranas y placenteras experimentadas durante la infancia.

El pasaje en cuestión organiza una imagen casi imposible: es la primera y única vez que el autor de las Confesiones logra plasmar el encuentro del niño con sus padres en la escena de lectura. El padre y el hijo leen juntos los libros de la biblioteca de la madre: es decir que de algún modo se unen a ella a través de los textos que constituyeron una clara preferencia en el gusto de la lectora: las novelas. Y digo que la imagen es casi imposible porque la madre de Rousseau muere durante el parto. El hijo obviamente no llega a conocerla o al menos a recordarla pero crece con una semblanza suya que guarda estrecha y profunda relación con este pasaje inicial de las Confesiones. La madre de Rousseau es 
una mujer distinguida e ilustrada: “mujer de esmerada educación. Dibujaba, cantaba, tocaba la tiorba, leía mucho y hacía versos discretos” (4) agrega el autobiógrafo en una nota al pie. Esta imagen de una madre desconocida, una madre muerta pero muy construida imaginariamente a partir del valioso legado de los libros está ciertamente idealizada: emerge en los comienzos del texto autobiográfico para explicar su influencia sobre el hijo. Un hijo también lleno de ideales que sale al mundo decidido a vivirlos.

Como señalé antes, las Confesiones son una de las obras probablemente más leídas a lo largo del siglo XIX y constituyen un punto de referencia obligado para la mayoría de los autobiógrafos europeos y americanos a la hora de incorporarse a una tradición. En el caso de Domingo F. Sarmiento, las remisiones son a menudo explícitas: a lo largo de Recuerdos de provincia varias veces irrumpe la comparación y la apelación a la figura y el pensamiento de Rousseau. De hecho, la crítica ha señalado y abordado los puntos de contacto entre estos dos autores. ${ }^{1}$ En este trabajo me interesa subrayar la influencia de la madre en la configuración autobiográfica de Sarmiento, con el objeto de analizar algunos aspectos referidos a la problemática de la lectura y la escritura. Para empezar, podríamos decir que cuando Sarmiento realiza sus primeras lecturas infantiles, así como cuando escribe Recuerdos de provincia su madre no está muerta. Pero la "historia de la madre" se desencadena a partir del temor por su muerte. Sarmiento imagina o más precisamente sueña primero y muy pronto alucina despierto (sin poder despojarse del influjo del sueño) que su madre ha fallecido mientras él se encuentra exiliado:

¡Pobre mi madre! En Nápoles, la noche que descendí del Vesubio, la fiebre de las emociones del día me daba pesadillas horribles, en lugar del sueño que mis agitados miembros reclamaban. Las llamaradas del volcán, la oscuridad del abismo que no debe ser oscuro, se mezclaban qué sé yo a qué absurdo de la imaginación aterrada, y al despertar de entre aquellos sueños que querían despedazarme, una idea sola quedaba tenaz, persistente como un hecho real: ¡mi madre había muerto! Escribí esa noche a mi familia, compré quince días después una misa de requiem en Roma, para que le cantasen en su honor las pensionistas de Santa Rosa, mis discípulas; e hice el voto y perseveré en él mientras estuve bajo la influencia de aquellas tristes ideas, de presentarme en mi patria un día, y decirle a Benavides, a Rosas, a todos mis verdugos: Vosotros también habéis tenido madre: vengo a honrar la memoria de la mía; haced, pues, un paréntesis a las brutalidades de vuestra política, no manchéis un acto de piedad filial. ¡Dejadme decir a todos quién era esta pobre mujer que ya no existe! iy, vive Dios, que lo hubiera cumplido, como he cumplido tantos otros buenos propósitos, y he de cumplir aún muchos más que me tengo hechos! (Recuerdos 174)

A diferencia de lo que sucede en las Confesiones, donde la muerte de la madre es una realidad que se atempera en parte con las reminiscencias que despiertan las lecturas compartidas, la madre muerta de Sarmiento es una fantasía que impulsa arranques violentos: intempestivos viajes imaginarios, ruegos a los tiranos, odios encendidos y una

\footnotetext{
${ }^{1}$ Me refiero, particularmente, al trabajo de Carlos Altamirano y Beatriz Sarlo, "Una vida ejemplar: la estrategia de Recuerdos de provincia”, en Ensayos argentinos. De Sarmiento a la vanguardia (1997) e "Identidad, linaje y mérito de Sarmiento", en Punto de vista 3/10 (1980).
} 
escritura inmediata y reinvindicatoria. El apartado sobre "La historia de mi madre" se escribe a partir de esas fantasías de muerte figuradas por el hijo y persiste al paso del tiempo, pese a que la madre sigue viva aún cuando el autobiógrafo escribe su texto y pese a que ella misma lo "instruye" sobre muchos de los recuerdos que el autor reconoce en su libro como propios. En Recuerdos de provincia la madre constituye un verdadero pretexto, es - como veremos - una usina de "dichos" y recuerdos que alimentan el relato autobiográfico. En este sentido puede decirse que la madre está en los orígenes de la escritura: participa de manera tangencial pero decisiva en la formación del escritor.

Pero inversamente a lo que sucede en las Confesiones, en la obra de Sarmiento la madre lectora es una figura imposible. La relación de Sarmiento con su madre es exactamente opuesta a la de Rousseau con la suya: Paula Albarracín no sabe leer o, lo que es peor, lo ha olvidado por falta de práctica. En la casa de Sarmiento no hay bibliotecas. De modo que en lo que se refiere a la relación del niño lector con sus padres, la tríada familiar se constituye de un modo diferente al de las Confesiones y asimétrico entre los integrantes de esta otra familia: en Recuerdos... emerge una madre analfabeta, "poco cultivada”, “destituida de todo ornato” y abocada al trabajo, junto a un padre desesperado por realizar el sueño del hijo prodigio: un niño ilustrado que aprende a leer sin maestros en una provincia con pocas institituciones y sin libros. Es el sueño del padre que va de casa en casa exhibiendo las raras habilidades de un niño que a los cinco años es capaz de leer en voz alta y de corrido libros muy complejos para su edad, frente a un auditorio que asiste conmovido al espectáculo de la lectura. Desde luego, el ejercicio de la lectura implica aquí la tenencia de una destreza poco común y la maravilla de poseerla tan tempranamente. Sarmiento narra este episodio en el capítulo titulado "Mi educación”.

Es interesante el juego de ostentación y renunciamiento que encara el texto en relación con la anécdota: porque aunque el autobiógrafo exhibe con orgullo su ilustración infantil, también confiesa que había "un secreto detrás de bastidores que el público ignoraba” (199) y que ahora está dispuesto a revelar. Además de las exhibiciones públicas, el padre y el hijo realizan en privado otro ritual diario: practican la lección durante horas, y leen "librotes abominables" que dejan en su espíritu "ideas confusas de historia, alegorías, fábulas, países y nombres propios” (199). De lo que se deduce que la ilustración de este lector precoz no es espontánea sino impostada. Se trata de una pura pose de prodigio porque el niño prácticamente recita en voz alta y de memoria los textos que tiene ante sus ojos, no los lee verdaderamente. Desde luego, el recitado es fruto del trabajo, del "esfuerzo" en las prácticas hogareñas. Y entonces podría decirse que este "secreto" confesado en la autobiografía revela una verdad doble: en primer lugar que el mentado prodigio del niño no es natural, y por lo tanto no existe como tal; en segundo lugar que ese esfuerzo temprano y denodado por convertirse en lector precoz deja secuelas conflictivas en el adulto: confusas ideas que empañan o ponen en tela de juicio la legitimidad de sus conocimientos frente a otros lectores menos prodigiosos pero más escolarizados.

Las consecuencias de la alfabetización compulsiva y del prodigio impostado se harán visibles en distintas situaciones narradas en Recuerdos..., situaciones que revelan a un niño normal y sencillo pero también a un adulto ambicioso que no se ha desprendido de 
las fantasías paternas. ${ }^{2}$ Un adulto narrador que también ostenta su capacidad multilingüe, su habilidad para traducir del inglés en una sola noche los sesenta volúmenes de Walter Scott, bajo una luz de vela, una gramática y un diccionario. O que vuelve a exhibir sin pudores sus saberes confusos sobre la vida de personajes célebres: “¿de dónde diablos me decía yo a mi mismo confundido, he sacado yo este maldito cuento?” (107), se pregunta Sarmiento respecto del escándalo producido a partir de su incursión en la biografía de la monja Zañartu. Y enseguida recuerda que la historia la había recogido de labios de su tío José: historia que “creía basada en autoridad de cosa juzgada y de ahora cien años” (107). Creo que hay que atender, precisamente, a esta y otras creencias de Sarmiento, que representan sin duda un modo poco científico pero muy antiguo de adquirir conocimientos: creer en lo que se escucha, en lo que se dice, creer también en la eficacia de ciertas imágenes... El aprendizaje (y el saber) sarmientino tiene mucho de creencia, de confianza en lo que enseñan los sentidos (el oído, el tacto, la vista). Y se apoya en buena medida sobre la necesidad de utilizar rápidamente, con cierta velocidad el conocimiento adquirido. Desde luego no se trata de una confianza ingenua sino de una apuesta a la efectividad de ciertos relatos. Es necesario aprovechar la historia de la monja Zañartu en un artículo periodístico y no hay tiempo para investigar los detalles o corroborar su veracidad: la historia tal como ha sido creída/aprendida es aprovechada para escribirla en el momento oportuno, así como durante la niñez era útil simular un conocimiento alfabético para provocar la admiración del público. Por eso, aunque los “errores” cometidos por el adulto empañan su reputación de hombre ilustrado frente a muchos de sus contemporáneos - y de eso dan cuenta la polémica con Godoy, los juicios de Gutiérrez sobre el Facundo, emitidos confidencialmente a Alberdi- creo que es sobre la base de esos "errores" que Sarmiento logra construir un estilo propio, original, efectivo.

ARChIVOS, LEGAdos

La crítica ha abordado desde diferentes ángulos la problemática de la lectura en Sarmiento. ${ }^{3}$ Me interesa detenerme en el trabajo de Sylvia Molloy, que inspira buena parte de mi interpretación actual de Recuerdos ... y donde se plantea la cuestión de la pose

\footnotetext{
${ }^{2}$ Está claro que en la relación de Sarmiento con su padre no hay nada de la poesía, la sensibilidad y el placer compartidos que transmite el relato de Rousseau, en una de las pocas (pero intensas) referencias a la figura paterna que ofrecen las Confesiones. Y aunque el padre de Sarmiento es un personaje claramente devaluado en el interior de Recuerdos — especialmente en contraste con la figura materna - resulta interesante este relato que lo exhibe como autor de un legado temprano y firme para el hijo: la ambición letrada.

${ }^{3}$ Desde diversas perspectivas, distintos especialistas han abordado la cuestión: Altamirano, Carlos y Sarlo, Beatriz, "Una vida ejemplar: La estrategia de recuerdos de provincia”, en Ensayos argentinos. De Sarmiento a la vanguardia, 1997; Ricardo Piglia, "Notas sobre Facundo", Punto de vista, 1980; Ramos, Julio, "Saber del otro: escritura y oralidad en el Facundo de D.F. Sarmiento", Desencuentros de la modernidad en América Latina. Literatura y política en el siglo XIX, 1989; Rosa, Nicolás, "El oro del linaje”, El arte del olvido, 1993; Prieto, Adolfo, “Sarmiento: Casting the Reader, 1839-1845" y Goodrich, Diana Sorensen, "The wiles of disputation: Alberdi reads Facundo”, ambos en Sarmiento, Author of a Nation, comps. Tulio Halperín Donghi, Gwen Kirkpatrick y Francine Masiello, University of California Press, Berkeley, 1994.
} 
autobiográfica. En este sentido, el título del trabajo es elocuente: "El lector con el libro en la mano” es para Molloy la imagen que sitúa un tópico en los textos de muchos autobiógrafos latinoamericanos: la puesta en escena del acto de la lectura, el "encuentro del yo con el libro" (28) como una escena constitutiva. Molloy destaca que los autobiógrafos latinomericanos suelen darle una importancia fundamental al momento de iniciación, de debut en las letras e incluso, suelen individualizar "el Libro de los Comienzos". A menudo esa escena está relacionada con un mentor que puede ser la madre, expresa Molloy. Y refiriéndose a Recuerdos... sostiene: "Sarmiento, unido a su madre por sentimientos tan intensos (...) nunca pudo combinar sus dos pasiones — la madre y los libros_ porque su madre no sabía leer” (30).

La observación es sagaz y estimulante. Apunta a una cuestión que considero fundamental en este texto autobiográfico: la relevancia de la figura de la madre analfabeta en Recuerdos... Personalmente creo que Sarmiento capitaliza esa imposibilidad de la misma manera como capitaliza las carencias, los errores, los aprendizajes compulsivos: exhibiéndolos y explotándolos en la escritura, produciendo relatos. En este sentido, creo que la ausencia de una biblioteca, e incluso, de una biblioteca materna resulta crucial y productiva en la avidez sarmientina por las lecturas y los libros. El afán de poseerlos (de leerlos, de escribirlos) surge fuertemente unido a la figura de esa madre analfabeta y trabajadora, tal como la recrea la memoria sarmientina. Para desarrollar esta hipótesis quiero contraponer una vez más Recuerdos de provincia con la obra de otro memorialista del siglo xix, que escribe y publica en un contexto muy diferente al de Sarmiento: hacia 1904, cuando tiene ya 82 años. Es decir que escribe alejado de las virulencias del rosismo, cuando el rosismo ya es historia pasada en Argentina, pese a que sigue despertando adhesiones, repudios y revisiones historiográficas. Me refiero a las memorias de Lucio V. Mansilla, sobrino de Rosas, hijo de Agustina Rosas y polémico contrincante de Sarmiento.

José Mármol esboza en Amalia una urticante descripción de la madre de Mansilla que enciende la ira del hijo, cuya reacción pública lo confina al exilio en la ciudad de Paraná. Desde la mirada de Mármol Agustina es una “belleza federal”: mujer hermosa pero rústica, cuya alma no ha sido cultivada en la sensible delicadeza que las lecturas románticas proporcionan a Amalia. A diferencia suya, la semblanza de Agustina trazada por la novela es la de una mujer banal y frívola. Con los años su figura adquiere un lugar relevante en las memorias del hijo y su obra nos ofrece otro ejemplo de la relación madre-niño-lectura, así como de la colocación del autobiógrafo en la escena familiar argentina del siglo XIX. Mis memorias (París, 1904) narra de la siguiente manera la experiencia del niño lector:

La señora había coleccionado cientos de cartas y hecho con ellas, poniéndoles tapas de cartón, un grueso infolio. Era para que nos acostumbráramos a leer letra manuscrita de toda clase (había alguna que al mejor se la daría) y para que supiéramos qué clase de amigos tenía mi padre.

Allí, en ese enorme mamotreto, verdadero legajo de varios, aprendí yo a conocer a querer algunos personajes, los de letra clara como el señor don Domingo de Oro. Las simpatías de mi hermana y las mías estaban en razón inversa de la mala letra de los personajes (220)

El pasaje ofrece varias cuestiones interesantes. Por una parte enfoca la imagen preponderante de la madre que enseña a los hijos a ejercitar la lectura a partir de esta suerte 
de manual confeccionado por ella misma, con el objeto exclusivo de instruir a los niños: se trata nada menos que de un legajo de cartas manuscritas de los corresponsales de la familia.

Vale la pena recordar que - a decir del autobiógrafo— en esta casa tampoco hay una biblioteca materna: Agustina no es una lectora y la biblioteca del padre está fuera del lugar donde habita el niño durante la primera infancia. ${ }^{4}$ Sin embargo, esta madre parece tener muy en claro las premisas fundamentales de la educación de sus hijos: Agustina los introduce en el mundo de la lectura a través de este legajo que — como veremos — presenta una funcionalidad variada y decisiva, ya sea que lo consideremos desde la perspectiva de la madre o desde la experiencia del hijo.

En primer lugar, el legajo provee a los niños una destreza si se quiere elemental: la lectura experta de letras manuscritas de distinto tipo. Un entrenamiento útil para los niños que, por su parte, explotan un plus: a través de la letra, de su forma, su tamaño, su cadencia ... llegan a vislumbrar el carácter, la personalidad de los corresponsales. Y de hecho esos corresponsales que son también asiduos visitantes de la casa resultan más o menos queribles por los niños en relación con la amabilidad o la rusticidad de su caligrafía. Pero además, de parte de la madre existe otro móvil importante: el legajo permite a los niños conocer los nombres de los allegados a la familia Mansilla. Y en este sentido la práctica de la lectura sirve para situarlos socialmente, para insertarlos en las redes de parentescos familiares, sociales y políticos. Esta práctica los perfila como dignos herederos de la casa. ${ }^{5}$

De manera que aunque estos padres "leen poco" — como aclara el memorialista—, las lecturas escogidas para los niños, así como la casa misma y sus rituales organizan una didáctica propia y sin dudas diferente a la de la familia provinciana de Sarmiento. La casa Mansilla está a menudo repleta de visitas prestigiosas, de criados que realizan todo tipo de servicios. Estamos frente a una casa marcada por la belleza y los brillos que el dinero es capaz de proporcionar. Y aunque no hay un mobiliario repleto de libros sí existen, en cambio, textos e imágenes a partir de las cuales es posible apr(h)ender la historia: la historia de la patria y la historia familiar.

Repasando los rincones del comedor doméstico, en Mis Memorias Mansilla afirma que “un solo cuadro lo adornaba: la batalla de Maipú” (147). El padre se "lo explicaba cada

\footnotetext{
${ }^{4}$ Los libros llegarán a la vida de Lucio un poco más tarde, para desencadenar otros conflictos en relación con lecturas impropias para el joven hijo de una familia rosista. En “¿Por qué?” Mansilla ofrece una versión sobre las causas de su primer viaje: el padre no encuentra mejor salida que un viaje para contener las apetencias de este lector inquieto perteneciente a la familia rosista: “- Mi amigo, cuando uno es sobrino de don Juan Manuel de Rozas, no lee el Contrato social, si se ha de quedar en este país; o se va de él, si quiere leerlo con provecho” (Mansilla 57).

${ }^{5}$ No hay que olvidar que se trata de una sociedad y particularmente de una familia fuertemente marcada por el estigma del rosismo. Y en este sentido, el autobiógrafo narra con dificultad pero también con esmero un aspecto crucial de la niñez: el cobijo y las comodidades que le provee la casa familiar pero también los miedos que se despiertan frente a ciertas situaciones incomprensibles para el niño, miedos que se desatan tras las puertas del hogar. Por ejemplo, la visión de unos “degollados” que yacen en el camino mientras los niños circulan en su carruaje durante un paseo vespertino. A la luz de estos recuerdos el adulto, el autobiógrafo que es Mansilla se debate entre el "amor” al tío, que marca fuertemente la niñez y la ética del adulto que debe reposicionarse y tomar partido en relación con ese pasado conflictivo (Véase Mis Memorias).
} 
vez que” encontraba a Lucio contemplándolo. Ese mismo comedor tiene aparadores y “cajones secretos” que contienen "cartas empaquetadas de infinidad de personajes, cartas que, a ocultas, solía yo leer” (147), confiesa el memorialista. Estos cajones repletos de cartas, legajos y archivos familiares constituyen los pasatiempos del niño Lucio a la hora en que la sala está vacía. Espiarlos es uno de los juegos favoritos durante la niñez.

Desde luego, la experiencia del autor de Recuerdos de provincia y su relación con la casa natal, con la madre, el padre y las lecturas es bastante diferente a la de estos otros dos memorialistas a los que nos hemos referido. En Sarmiento la lectura carece del placer que experimenta Rousseau en su encuentro literario con los padres y también de la utilidad de la lectura de Mansilla con los suyos. Es decir de ese tipo de utilidad mediante la cual la madre le lega al hijo un caudal de escritos en los que se inscribe el nombre propio. Y el nombre es precisamente para Sarmiento una meta a veces inalcanzable y casi siempre extremadamente ambiciosa: en Recuerdos... narra sus esfuerzos para confirmar si el nombre de un pico de la cordillera conmemora a la familia Sarmiento —algún ascendiente suyo - o se trata de una casualidad. La ambición por el nombre propio puede relacionarse con otro término muy usado en el texto: el "barniz" que a menudo modela los rostros de los personajes exaltados de Sarmiento y que puede leerse en serie con la estatuaria y el bronce. "Nombre” célebre, "barniz", "bronce”, “estatua”, son términos textuales de Recuerdos... y metas del autobiógrafo.

No es difícil imaginar cuántas cosas hubiera logrado hacer Sarmiento con un epistolario como el de Mansilla. Sin duda lo hubiera citado ampliamente y hubiera utilizado ese material como un elemento probatorio de los parentescos sociales, intelectuales o amorosos con las familias más ilustres de la historia nacional, pudiendo así probablemente- dejar de lado ese forzado mapa genealógico que precede las páginas de Recuerdos... ${ }^{6}$ Sin embargo, lo cierto es que ésta es también una ilusión irrealizable para Sarmiento: puesto que no hay madre lectora, no hay biblioteca y no hay tampoco interlocuciones prestigiosas de los padres/del padre que permanezcan archivadas en una carpeta o legajo de familia, el comienzo de Recuerdos de provincia exhibe el compulsivo esfuerzo de un autobiógrafo empeñado en narrar y documentar no sólo sus parentescos genealógicos e intelectuales sino también su inserción personal y familiar en la historia sanjuanina.

El problema es que tampoco hay una historia sanjuanina: Sarmiento expresa su estupor frente al hallazgo infructuoso de materiales durante el inventario en casa de una familia sanjuanina de renombre:

Entre los papeles viejos encontróse (...) una carpeta que envolvía manuscritos con este rótulo: "Este legajo contiene la Historia de Cuyo por el abate Morales, una carta topográfica y descriptiva de Cuyo, y las probanzas de Mallea”. Hubo de caer alguna vez bajo mis miradas esta leyenda, y yo quise ver aquélla suspirada historia de mi provincia. Pero, ¡ay!, no contenía sino un solo manuscrito, el de Mallea, con fecha del año 1570, diez

\footnotetext{
${ }^{6}$ Remontar genealogías y organizar la ascendencia materna y paterna parece un gesto que se reitera en los autobiógrafos argentinos. Pienso en el caso de Victoria Ocampo, que agrega "apéndices" autobiográficos donde procura testimoniar su descendencia de los amores de Irala —el conquistador español— con la india Agueda. Véase el tomo I de la Autobiografía.
} 
años después de la fundación de San Juan. (...) He aquí, pues, el leve y desmedrado caudal histórico que pude por muchos años reunir sobre los primeros tiempos de San Juan: aquéllas palmas antiguas, la inscripción jesuítica y la carpeta casi vacía. (...) Practícanse diligencias en Roma y en Bolonia en busca de los manuscritos abolengos, y no pierdo la esperanza de darlos a la luz pública un día. (Recuerdos 77)

No hay materiales ni archivos, tampoco en las arcas provinciales. Solamente una carpeta vacía que alienta la imaginación histórica. Frente a esta carencia exhibida en las primeras páginas de Recuerdos... puede decirse que si bien es cierto que, como señala Sylvia Molloy, la autobiografía de Sarmiento sostiene ostentosamente la pose del lector con el libro en la mano e incluso busca individualizar un "Libro de los Comienzos", también es verdad que en los comienzos de este libro emerge sobre todo la exhibición de un gran vacío original, de una falta inscripta en la historia personal y provincial. Una doble carencia que acusa la falta de documentos probatorios de las interlocuciones familiares y la falta de archivos que provean un cierto estatus a la historia de San Juan.

Creo que una de las cuestiones más interesantes que se ponen de relieve a lo largo de Recuerdos... es la exhibición de estas carencias y la exhibición también de las destrezas para desafiarlas. Pese a todos esos vacíos la historia personal y provincial logra emerger cargada de enigmas, brillos y atractivos. $\mathrm{O}$ tal vez sea más preciso afirmar que son esos vacíos y carencias los que impulsan la escritura sarmientina.

\section{SARMIENTO. LECTOR DE IMÁGENES}

Existe una fuerte relación de causalidad entre la escritura combativa y desafiante de Sarmiento y su formación como lector. Como es sabido, Sarmiento aprende a leer con materiales muy precarios desde el punto de vista de la enseñanza ilustrada. Retomemos una frase de la cita anterior, cuando el autor expresa: "hubo de caer bajo mi mirada esta leyenda y yo quise ver aquélla suspirada historia de mi provincia”.

La carpeta de Mallea ha caído bajo la mirada de Sarmiento, que quiere ver, es decir leer. Aquí aparece claramente un axioma: para el autor de Recuerdos de provincia ver es leer. Y leer es ver. Basta recordar la avidez con la que en este texto se miran los rostros y las bocas de los maestros e incluso se procura imitarlos. A propósito de José de Oro (uno de los primeros maestros) Sarmiento elogia "su oratoria concisa, llena de sensatez y de ideas elevadas, expresadas en lenguaje fresco” (105) y se explaya luego sobre su propia capacidad de ser influenciado, de impregnarse de la palabra y de la imagen del otro.

Sarmiento es antes que nada — quiero decir en sus orígenes y en su estilo de escritorun lector de imágenes. Y por lo tanto un lector primitivo, un lector iletrado, lo cual no es del todo una paradoja. Puesto que los iletrados también leen, de hecho, una amplia variedad de íconos culturales: imágenes, signos, marcas, huellas como aquéllas que Sarmiento asegura en Facundo que leía Calibar. Un rastreador experto en reconocer las pisadas de bandidos en fuga y encontrarlos donde nadie hubiera sido capaz de develar una mínima señal. Sarmiento tiene algo de la sensibilidad del rastreador. Pero sobre todo tiene el “candor” (una palabra elegida por el autor de Facundo) de un espectador analfabeto que 
se deslumbra y emociona frente a la sensibilidad estética o religiosa de ciertas imágenes. ${ }^{7}$ Para comprender mejor esa disposición de Sarmiento a los íconos visuales (la imagen, el espectáculo), recordemos por ejemplo a los fieles que contemplan las escenas religiosas en las pinturas de las catedrales europeas, durante la Edad Media o el Renacimiento: la mayoría de ellos son analfabetos y quizá por eso mismo su capacidad para dejarse conmover por los cuadros religiosos se conserva intacta. La sensibilidad y la emotividad de las imágenes organizan un relato sobre la vida de los santos. Los vitraux también suelen contar esas historias. Los de la catedral de Milán, por ejemplo, son famosos por su capacidad narrativa. El poder de las formas, los colores y los relieves sobre los cristales arrastran todavía a numerosos visitantes, fieles o ateos que acuden a contemplar su belleza. Podría decirse que toda la iconografía religiosa apunta a esto, es decir a que los fieles lleguen a leer las imágenes y aprenderlas.

Alberto Manguel asegura que a finales del siglo xiv y a lo largo de la Edad Media los libros de imágenes se vuelven tremendamente populares: "volúmenes con dibujos a toda página, meticulosas miniaturas, grabados en bloques de madera entintados a mano, finalmente, en el siglo xv, tomos impresos" (143). Con el tiempo, estos libros se conocen bajo el nombre de Bibliae Pauperum o Biblia de los Pobres, agrega Manguel. ${ }^{8}$ El título es por demás elocuente e ilustra la idea de la lectura analfabeta: los iletrados leen, también ellos, imágenes. Creo que Sarmiento tiene por ellas una predilección que se evidencia en muchas de sus lecturas y sobre todo en la escritura.

En Recuerdos de provincia la destreza oral de los maestros encanta al discípulo, que se deja impregnar no sólo por las voces sino también por la belleza de los rostros y las fisonomías. ¿Cómo son los sabios para Sarmiento? podríamos preguntarnos. Y Recuerdos... parece dar una respuesta contundente: los sabios son bellos, son hermosos, hablan con elocuencia, despliegan una sonrisa en los labios, incluso son capaces de inspirar comparaciones con la pintura de artistas célebres o con los espectaculares decorados de una ópera parisina. Los sabios hacen del aprendizaje un placer, emocionan, conmueven al alumno y así imprimen en él ciertos conceptos que nunca más serán olvidados: “Mi inteligencia se amoldó bajo la impresión de la suya” (140), afirma Sarmiento refiriéndose a José de Oro.

Imprimir aquí adquiere el sentido de grabar, de esculpir, de dejar una huella sobre el terreno del otro. Lo que Sarmiento no puede olvidar es sobre todo el modo de experimentar el aprendizaje: un modo cargado de sentimientos y sentimentalismos. La admiración por José de Oro imprime en él una sensibilidad y emoción de las que el adulto no reniega en absoluto. Es en este sentido que José deja su huella en la inteligencia sarmientina. Las impresiones que se experimentan a su lado afectarán directamente la escritura del

\footnotetext{
${ }^{7}$ De hecho, Sarmiento lee completa la Biblia y varios libros religiosos. Y aunque asegura tener una educación religiosa "pero liberal” cede por momentos al influjo poderoso del canónigo Ignacio Castro Barros, aquél que "fascinaba” a las mujeres en la Iglesia azuzándolas con la idea de la presencia del demonio. Sarmiento duda recién cuando la mise en scène de Castro Barros toca el punto del delirio. Pero su histrionismo fascina al espectador a tal punto que el relato forma parte de esa cadena de anécdotas que, aunque funcionales al todo del relato, el autobiógrafo no puede ni quiere privarse de narrar.

${ }^{8}$ Manguel, Alberto, “Lectura de imágenes”, en Una historia de la lectura (1999) 133-49.
} 
discípulo. Sarmiento inscribe en Recuerdos... un episodio significativo: durante una lección el maestro le dicta una leyenda religiosa cargada de dramatismo. José está narrando el milagro de un santo y el llanto comienza a "humedecer su voz". Influenciado por la emotividad de la anécdota y la del maestro, al discípulo se le “anublan los ojos” y "gruesas lágrimas echan a perder lo escrito”. Maestro y discípulo se abrazan, sollozan juntos y José dictamina: “Dejémosle para mañana... Somos unos niños” (Recuerdos 106).

Esta vez la emoción ha interrumpido y echado a perder la escritura. Pero el proceso de andadura de Recuerdos... pone en evidencia un aprendizaje fundamental realizado por Sarmiento, que con los años parece haber aprendido como ninguno a escribir con la emoción y por la emoción: es decir movido por ella. En Recuerdos... como en Facundo y tantos otros de los textos de este autor americano la emoción no obstruye la escritura sino que, por el contrario, la hace fluir a borbotones y la impregna de personalidad y estilo.

Sarmiento rescata y valora a ese lector primitivo que fluye bajo la pluma de sus textos. Por eso Recuerdos de provincia exhibe, por una parte, los aprendizajes y los materiales de aprendizaje de un niño en la pobreza y a partir de ellos construye una imagen sobre las maneras que tiene el adulto — es decir el escritor— de producir saberes y relatos, más allá o más acá de los libros leídos. Si bien en Sarmiento hay muchas lecturas compulsivas, hay sobre todo una escritura confiada a lo imaginario, a la verdad de la invención. Una escritura que se figura lo que no sabe: "me figuro a los primeros colonos de San Juan, en corto número en los primeros años, careciendo de todas las comodidades de la vida” (81), dice Sarmiento tras comprobar que los manuscritos de Mallea constituyen una carpeta vacía de documentos.

Cada vez que Sarmiento no puede, de hecho, leer en los libros, en los folios, en los archivos... acude a su imaginación, recrea los hechos en una versión propia, original, inventada, que se erige como fuente de verdad, pretendiendo asumir el valor de un documento. Recuerdos... permite avizorar por lo menos algunas funciones de la escritura sarmientina: ¿para qué se escribe? podríamos preguntarnos. Y el texto responde: se escribe para llenar vacíos. Es decir, pese a que pero también porque no hay manuscritos; se escribe para palear la injusticia; se escribe para producir hechos que afecten la realidad. Y en este sentido la escritura de Sarmiento es siempre política. ${ }^{9}$

Recuerdos muestra ese proceso por el cual de la nada es posible crear algo. De la carencia de libros y manuscritos, de la carencia de una biblioteca materna es posible, por medio de ciertas operaciones vinculadas con la imaginación, llegar a componer una historia personal, un libro inolvidable para la cultura nacional. En este sentido, la carpeta vacía y la biblioteca inexistente son espacios fundantes de la escritura sarmientina. O dicho de otro modo, Recuerdos... narra la llegada a la escritura de un niño sin libros. Una llegada muy mediada por los maestros y entre ellos por una gran maestra que es la madre, una madre que ha “olvidado” leer.

\footnotetext{
${ }^{9}$ Explorando el carácter "pasional”, “incongruente” y "contradictorio” del discurso sarmientino, Carlos J. Alonso se ha referido especialmente al aspecto fáctico, "performativo" de su escritura. Véase, Alonso, Carlos J, "Reading Sarmiento. Once More, With Passion”, en The Burden of Modernity. The Rhetoric of Cultural Discourse in Spanish America (1998).
} 
LA VOZ DE LA MADRE

El aprendizaje con la madre tiene un punto de contacto con uno de esos rasgos que deleitan al alumno: la voz de los maestros. En Recuerdos... la madre es sobre todo una $\mathrm{voz}$ que susurra, que rumorea historias y que habla a través del hijo. Los “dichos” de Doña Paula tienen un lugar preponderante en el interior del texto: ella dicta ciertos fragmentos, aunque la suya no sea nunca una voz autoritaria. Más bien parece darse aquí un cierto intercambio entre madre e hijo: ella provee los relatos que aportan al autobiógrafo un caudal importante para completar la historia personal y provincial, mientras el hijo se convierte en una suerte de mediador, de secretario de la memoria, la voz y los recuerdos maternos.

Me interesa tomar un relato que habla de este intercambio: un episodio que está fuera de lo que Sarmiento titula la "historia de la madre" y que enfoca un episodio referido a la cultura virreinal que es también una experiencia materna. Me refiero al episodio del asoleo, que está promediando los comienzos de Recuerdos... antes de que comience a desplegarse el anecdotario referido a los maestros. Se puede decir que Sarmiento escribe este episodio bajo la forma de un relato autónomo, como un pequeño fragmento romántico que se anticipa a la historia de la madre propiamente dicha.

Se trata de una de las primeras veces que la voz y la figura de la madre emergen en el texto y lo hacen con una enorme contundencia. El episodio construye la imagen de una madre niña que espía, subida a los brazos de una negra esclava el oro de una familia rica a la que no pertenece. La espía participa con la mirada de una especie de ritual llevado a cabo una vez al año por los criados de la casa de la tía Antonia:

Cerrábanse las gruesas puertas de la calle, claveteadas de enormes clavos de bronce, y poníanse en incomunicación ambos patios, para apartar a la familia menuda; entonces, cuéntame mi madre que la negra Rosa, ladina y curiosa como un mico, le decía en novedosos cuchicheos: ¡hoy hay asoleo! Aplicando con tiento en seguida una escalera de mano a una ventanilla que daba hacia el patio, la astuta esclava alzaba a mi madre, aún chicuela, cuidando que no asomase mucho la cabeza, para atisbar lo que en el gran patio pasaba. Cuan grande es, me cuenta mi madre, que es la veracidad encarnada, estaba cubierto de cueros que tendían al sol en gruesa capa pesos fuertes ennegrecidos, para despejarlos del moho; y dos negros viejos eran depositarios del tesoro, andaban de cuero en cuero removiendo con tiento el sonoro grano. (Recuerdos 102)

Todo el fragmento en el que se enmarca este pasaje resplandece con la belleza del oro. Porque antes de que la mirada de la madre niña y la pluma del autobiógrafo se detengan a contemplar la escena del asoleo en sí misma, sobreviene toda una descripción morosa sobre de la casa de la tía Antonia y sus esclavos, sobre las innumerables bellezas y los lujos de esta casa virreinal. Entonces emergen frente a los ojos de los lectores las “orpas”, la “orquesta”, las "sonatas”, los "perfumes”, los “candelabros de plata”, los “faldellines de brocato, damasco o melania", las "medias de seda de colores", las "telas preciosas recamadas de oro”, las “piedras preciosas”, los “diamantes”, los “encajes de Holanda”, los "zarcillos enormes de topacios, gargantillas de coral y el rosario de venurinas", las “piedras preciosas de color café entremezcladas de oro (...) torneadas en espiral y grandes 
como huevos de gallina” (102)... Un mundo dorado, ampuloso, brillante e inalcanzable para una niña pobre cuyos ojos se deleitan contemplando. Este brillo esplendoroso despierta en el texto el imaginario del oro. No hay que olvidar que el fragmento sobreviene justo antes de aquél otro que lleva por título: “Los Oro” y que, desde luego, hace referencia a un oro simbólico e intelectual: el de los maestros.

Sin embargo, este otro oro resplandeciente del asoleo resulta un oro muy tangible y concreto. No es tampoco el oro deseado pero a menudo inalcanzable que prometen los derroteros americanos, de los cuales el texto se ha ocupado en las páginas anteriores. No es ese oro soñado que promueve búsquedas y peregrinaciones sino uno muy real y tangible, que incluso tiene un dueño y un depósito donde se guarda para que sea protegido, amurallado por paredes y por puertas, escondido de la codicia de los ladrones. Este es un oro, puede decirse, que lleva nombre y apellido.

Esa morosidad en la descripción de los objetos parece reproducir —no es difícil imaginarlo_- la mirada morosa de la espía: el encantamiento, la fascinación de esta madre niña pobre que es testigo de la ostentosa riqueza de un pariente que pertenece a la rama afortunada de la familia. Tal como la construye Sarmiento, la escena de la espía en sí misma logra ubicar a la madre en relación con un sistema de jerarquías que provee al fragmento su propia cuota de dramaticidad: la niña espía el oro de su tía — un oro ajeno- subida a los brazos de una negra esclava. La tía rica, la madre pobre, la esclava. El trío de algún modo anticipa la colocación social de la familia Sarmiento, un poco a caballo entre dos mundos: es decir, con linaje pero sin dinero. Con una riqueza que está próxima pero es ajena. Más tarde, ya en el interior de "La historia de mi madre” veremos reproducirse, con otros protagonistas, un trío también jerárquico pero sin ricos. La madre y las criadas: Toribia, “una zamba criada en familia”, que es el "brazo derecho” de Paula Albarracín, y Ña Cleme "el pobre de la casa”, porque la madre —afirma el hijo_— "no se mesquinaba nada, tenía también sus pobres a quienes ayudaba con sus desperdicios a vivir” (Recuerdos 188). Estas criadas pobres de una madre pobre vienen a recordarnos la dignidad “decente” de esta familia que en su pobreza guarda las formas de su antigua prosapia y que no llega jamás a la indigencia.

En otro nivel de análisis y tríadas, el propio Sarmiento hijo protagoniza una posición intermedia en el interior de la casa familiar: la madre impone la disciplina del trabajo, pero el padre prácticamente le prohibe al hijo realizar trabajos manuales, porque - como hemos visto- aspira a un ascenso social que debe obtenerse con esfuerzo intelectual. Evidentemente las relaciones de familia establecen vínculos crispados de tensión, que ponen en evidencia las desigualdades y provocan ambiciones a veces insatisfechas para algunos de sus miembros. Pero sobre todo, puede decirse que encienden deseos persistentes que pujan por realizarse, aunque más no sea en el plano de lo simbólico. Pienso concretamente en la escritura del hijo. La mirada encantada de la madre niña, su deseo casi tangible se deposita con un cierto regocijo en la escritura de este texto de Sarmiento. O para decirlo con una palabra que él utiliza para explicar su capacidad de ser influenciado por los maestros: el deseo de la madre transmigra al hijo bajo la forma de una cierta codicia por el oro virreinal, ese oro que no es posesión de la familia. Un oro real y concreto que no se hereda. Y en ese sentido la escritura sarmientina no puede resistir la tentación de salir al encuentro de ese recuerdo, de salir a la conquista de ese oro casi como si estuviéramos 
leyendo el texto de un conquistador americano: "Hay episodios tan curiosos de la vida colonial, que no puedo prescindir de referirlos” (101), explica el narrador. Para Sarmiento, escribir es apropiarse del terreno. Apropiarse de las joyas y los brillos para echar sobre este texto que quizá más que ninguno exalta el nombre propio, un áurea de resplandor, un manto dorado que impregna con su encanto la historia personal. El gesto no es de ningún modo excepcional: recordemos que antes de poner en pie la primera escuela Sarmiento traza mapas, escribe programas. Durante la niñez copia, calca, dibuja rostros de héroes, posiciones de soldados: ensaya y practica, pergeña o prefigura los asentamientos.

\section{EL ORO Y EL MORO: UNA ESCRITURA LUMINOSA}

Sarmiento asegura entonces, y habrá que creerle, que “no puede dejar de referir” este episodio curioso de la vida colonial. Aflora en esta declaración otro rasgo de la escritura sarmientina: la incontinencia. No se desea ni se puede contener el impulso letrado, particularmente cuando está impregnado del deleite, del placer de la narración por ella misma. Y también porque en el autor de Facundo y Recuerdos de provincia existe otra constante: escribir tentado por las figuras que lo impresionan: por la belleza del oro, por los prodigios del héroe, por los enigmas de la historia... por todo aquello que en primer lugar ha impresionado al escritor y luego puede impresionar y atrapar a los lectores. Porque antes, el lector que es Sarmiento ha aprendido a desear la belleza, a cultivar la imaginación y a figurarse aquello que no posee. Son estos tres movimientos los que afloran como recursos productivos frente a la carencia de archivos y saberes prestigiados.

Desde luego, el episodio del asoleo exhibe también un cuarto movimiento de la escritura sarmientina: la funcionalidad de la anécdota narrativa, por gratuita que ella parezca. Darle a la imagen o escena compuesta con deleite un uso ad hoc, una utilidad adecuada a otros fines más trascendentes que el puro gozo de narrar o leer un fragmento dado, es también una característica frecuente del autor de Facundo. La historia de Quiroga contada por Sarmiento está repleta de hechos prodigiosos narrados con enorme deleite y que podrían interpretarse como relatos autónomos pero que conforman, junto con otros, una cadena de anécdotas biográficas que buscan un efecto de lectura. El episodio del asoleo, ya referido, finaliza con una suerte de coda reflexiva del autor donde Sarmiento explota, digamos que políticamente, la aventura narrativa:

Fue la manía de los colonos atesorar peso sobre peso, y envanecerse de ello. Aun se habla en San Juan de entierros de plata de antiguos, tradición popular que recuerda la pasada riqueza (...) Qué se han hecho, oh, colonos! Aquéllas riquezas de vuestros abuelos? (...) Las colonias españolas tenían su manera de ser, y lo pasaban bien bajo la blanda tutela del rey. (Recuerdos 102)

En este momento la dignidad de la pobreza se suspende en virtud de la nostalgia por la riqueza del pasado en sus formas más puras: el oro, sin metáforas. Uno podría preguntarse ¿qué es lo que le sucede a Sarmiento que aquí parece olvidar quiénes son los que lo pasaban bien bajo la tutela del rey? Hay en este párrafo una suerte de nostalgia por la bonanza colonial con todo lo que ella implica: la esclavitud, la brutalidad de la conquista, la realeza previa a la Independencia. Esta añoranza que también emerge en otras 
partes de la obra y que subraya una inclinación demasiado fuerte o explícita por parte del autor respecto del pasado colonial no se condice del todo con el espíritu republicano de Sarmiento. Sin embargo, creo que ella es posible porque se recuesta sobre una denuncia al presente: una denuncia al rosismo que justifica toda añoranza. ${ }^{10}$ El relato pasa dramáticamente del oro de la colonia y su nostalgia a una feroz crítica sobre los "veinte años de federación transcurridos” en el medio y la devastación producida durante ellos. Desde luego, Sarmiento empalma una frase con otra y explica cómo la belleza colonial debió haberse transformado en este intermedio, y debió haber configurado el cuadro de un país civilizado y moderno: regado de “correos, telégrafos, diarios, discusión”... Porque, finalmente, "la riqueza de un pueblo moderno es hija sólo de la inteligencia cultivada" (Recuerdos 103), asegura.

Con las ventajas del narrador que primero ha cultivado el placer del texto y tiene consigo a los lectores, el ataque al rosismo se realiza ahora con todos los bríos y desde todos los ángulos posibles:

1) desde la denostación argumentativa, que intenta probar que Rosas y su sistema de gobierno es contrarrepublicano (y esto podríamos continuar leyéndolo por ejemplo en la historia de Domingo de Oro)

2) desde la condena a la falta de ética humana: Rosas no sólo degüella a sus adversarios en este texto, sino que manda a matar nada menos que a Maza: quien "le enseñó a leer”. Y esto tiene sin dudas un peso muy fuerte en un libro que exalta a los maestros.

3) desde la condena simple y llana a la rusticidad del rosismo. La barbarie de los iletrados es aquí la barbarie del mal gusto. Rosas ha destruido la belleza, el decoro, la cortesía: todos los pilares de una sociedad civilizada.

La añoranza del oro se sostiene entonces cómodamente sobre la crítica al rosismo. Como si se dijera: la barbarie rosista no sabe gozar de la belleza. Aquí es cuando Sarmiento deja descansar su pose de joven pobre y puede — al menos por un momento — proferir el lamento por el oro perdido de la familia y exhibir el gusto por las riquezas. Emerge entonces sin reparos ese deseo antiguo, casi ancestral y heredado de la madre niña que por fin puede ser enunciado y escrito, porque al hacerlo se pone de relieve una vez más la rusticidad del enemigo.

FIGURACIONES Y PRODIGIOS; LA EFICACIA Y EL ARTE DE NARRAR

Como decíamos previamente, la escena del asoleo anticipa pero también completa la "historia de la madre”. Completa un panorama sobre el legado materno, que se evidencia como muy productivo y que no se limita en absoluto a la dignidad del trabajo, el sacrificio y la modestia sino que proyecta lo que podríamos llamar las figuras del deseo en la

10 “Carriles, Rosas, Rojos, Oros, Rufinos, Jofrés, Limas, y tantas otras familias poderosas, yacen en la miseria y descienden de día en día a la chusma desvalida. Las colonias españolas tenían su manera de ser, y lo pasaban bien pero vosotros habéis inventado reyes con largas espuelas nazarenas y apenas desmontados de los potros que domaban en las estancias, creyendo que el más negado es el que mejor gobierna. La riqueza de los pueblos modernos es hija sólo de la inteligencia cultivada” (Recuerdos 103). 
escritura sarmientina. ${ }^{11}$ Me refiero a ciertas figuras muy primarias, que se despliegan un poco por debajo del gran deseo explícito de la adquisición del saber por los libros y de la adquisición del poder a través del nombre. Esas figuras son el oro, los santos, los soldados (el mapa que conforman los juegos y los relatos infantiles). El texto escribe y yo diría que sobre-escribe en distintos momentos y niveles ese deseo ancestral y familiar por el oro. Así como escribe el fervor infantil por las figuras de santos y soldados: por sus rostros clavados en los muros de la casa materna. Recrear esas figuras del pasado permite de algún modo rellenar aquéllas páginas vacías: las de la historia personal y provincial. No hay archivos, ni pruebas manuscritas, ni espistolarios pero Sarmiento narra a partir de las anécdotas oídas, de las costumbres vividas, de todo lo que se experimenta a través del impacto de los sentidos y que permite traer al presente de la escritura los símbolos del pasado y sus ídolos destronados. En este sentido creo que esas figuras del deseo que yacen por debajo de casi todas las anécdotas sarmientinas son potentes y creativas: estimulan la imaginación literaria e histórica del escritor. Una imaginación acusada a menudo — por sus contemporáneos- de excesos y figuraciones. No hay más que recordar las recomendaciones de Alsina y su larga lista de correcciones a la edición de Facundo, que desde luego fueron completamente descartadas por el autor. ${ }^{12}$

Pese al rigor solicitado por Alsina, Sarmiento no corrige los “excesos” sino que busca un cierto tipo de eficacia en los textos, que tiene mucho que ver con capturar a los lectores, con la búsqueda de un público amplio y heterogéneo, un público — ¿por qué no?— de apasionados. Esa eficacia (señalada ya por Jorge Luis Borges en un prólogo a Recuerdos de provincia) se logra apostando a una retórica cargada de dramatismos, tensiones y figuraciones. Y es en este sentido que — contra los reclamos de Alsina — la imaginación poética del historiador resulta adecuada. Si en Mi Defensa Sarmiento ostenta haber aprendido a "leer muy bien” (49) y si esta afirmación puede interpretarse como un aprendizaje que implica saber desechar lo que no interesa y tomar de los textos lo que importa al lector, aquello que le resulta útil de acuerdo al rumbo particular de su lectura, las obras de Sarmiento también parecen evidenciar que su autor ha aprendido a escribir muy bien: a narrar lo que conviene al autor para erigirse como tal, desplegando un relato original, más allá del rigor historiográfico. Para terminar, podríamos agregar que Sarmiento parece vencer, transformándolo, aquél viejo desafío impuesto por el padre: pasa de ser un niño prodigio — un simulado niño prodigio — a ser un escritor que confía en los prodigios de la literatura para ejercer su peso sobre los hechos culturales, sociales y políticos.

\footnotetext{
${ }^{11}$ En "El oro del linaje" Nicolás Rosa subraya otro aspecto del legado materno exaltado por Sarmiento: la ética de la "verdad". A diferencia del padre, la madre siempre dice la verdad. Sin embargo, a partir del episodio del asoleo es posible pensar que la madre también lega al hijo un imaginario regido por las leyes del deseo. Es decir no sólo la moral y el trabajo sino la inventiva. ${ }^{12}$ Bien al comienzo de su larga lista de notas correctivas del Facundo, Alsina explica a Sarmiento: "Pues entonces le diré que en su libro, que tantas y tan admirables cosas tiene, me parece entrever un defecto general —el de la exageración: creo que tiene mucha poesía, sino en las ideas, al menos en los modos de locución. Ud. no se propone escribir un romance, ni una epopeya, sino una verdadera historia social, política y hasta militar a veces, de un período interesantísimo de la época contemporánea. Siendo así, forzoso es no separarse en un ápice —en cuanto sea posible- de la exactitud y rigidez histórica; y a esto se oponen las exageraciones” (Alsina 255).
} 
Alonso, Carlos J. The Burden of Modernity. The Rhetoric of Cultural Discourse in Spanish America. Nueva York-Oxford: Oxford University Press, 1998.

Altamirano, Carlos y Sarlo, Beatriz. "Una vida ejemplar: la estrategia de Recuerdos de provincia”. Ensayos argentinos. De Sarmiento a la vanguardia. Buenos Aires: Ariel, 1997. 13-67.

“Identidad, linaje y mérito de Sarmiento”. Punto de vista 3/10 (noviembre 1980): 14-19.

Alsina, Valentín. “Notas al libro Civilización y Barbarie”. [1901] Facundo o civilización y barbarie (con prólogo de Noé Jitrik; notas y cronología de Nora Dottori-Susana Zanetti). Caracas: Biblioteca Ayacucho, 1977. 255-304.

Goodrich Sorensen, Diana. Facundo and the Construction of Argentine Culture. University of Texas Press, 1996.

Halperín Donghi, Tulio, Gwen Kirkpatrick y Francine Masiello (comps.). Sarmiento, Author of a Nation. Berkeley: University of California Press, 1994.

Manguel, Alberto. Una historia de la lectura. José Luis López Muñoz, trad. Barcelona/ Buenos Aires: Grupo editorial Norma, 1999.

Molloy, Sylvia. Acto de presencia. La escritura autobiográfica en Hispanoamérica. México: Fondo de Cultura Económica, 1996. Edición original en inglés: At Face Value: Autobiographical Writing in Spanish America. Cambridge y Nueva York: Cambridge University Press, 1991.

Piglia, Ricardo. “Notas sobre Facundo”. Punto de vista III/8 (marzo-junio, 1980): 15-18.

Ramos, Julio. "Saber del otro: escritura y oralidad en Facundo de D.F.Sarmiento". Desencuentros de la modernidad en América Latina. Literatura y política en el siglo XIX. México: Fondo de Cultura Económica, 1989. 19-34.

Rosa, Nicolás. "El oro del linaje”. El arte del olvido. Buenos Aires: Puntosur, 1993.

Rousseau, Juan Jacobo. Confesiones. Santiago Cunchillos, trad. México: Porrúa, 1985. Sarmiento, Domingo F. Facundo o civilización y barbarie (con prólogo de Noé Jitrik; notas y cronología de Nora Dottori- Susana Zanetti). Caracas: Biblioteca Ayacucho, 1977.

Recuerdos de provincia. Buenos Aires: Kapelusz, 1966.

Mi Defensa. Recuerdos de provincia. Buenos Aires: Kapelusz, 1966. 